\title{
The United Nations Peacekeeping Operations and Challenges
}

\author{
Athambawa Sarjoon \\ Department of Political Science, \\ University of Peradeniya, \\ Peradeniya 20400, Sri Lanka \\ Corresponding Author \\ Mohammed Agus Yusoff \\ Center for Policy and Global Governance, \\ Faculty of Social Sciences and Humanities, \\ Universiti Kebangsaan Malaysia, \\ UKM Bangi 43600, Selangor, Malaysia
}

Doi: 10.36941/ajis-2019-0018

\begin{abstract}
The United Nations (UN) is mandated to maintain international peace and security. The UN attempts to achieve this mandate through different means including peacekeeping by deploying personnel and experts in conflict situations. The UN has adopted number of policies and mechanism to strengthen its peacekeeping operations. Although there are number of activities focusing on peacekeeping with notable successful operations, the UN still face issues and challenges which have been negatively influencing the efficiency, effectiveness and the success of its peacekeeping operations. This paper has attempted to examine the key activities of UN peacekeeping operations, their impact, and the major issues that negatively influence and challenge the peacekeeping operations. The study has found that the UN peacekeeping operations have worked effectively in managing conflict situations and establishing peace in many parts of the world. However, the shortcomings and issues particularly in terms of political, military and humanitarian aspects of the operations have negatively influenced the peacekeeping operations in achieving their targets successfully. The study urges the importance of policy and institutional reforms together with commitments of parties, institutions, and involving actors in order to strengthen peacekeeping operations and establish sustainable peace in many corners in the world.
\end{abstract}

Keywords: United Nations, Peacekeeping, political challenges, military challenges, humanitarian challenges, sustainable peace

\section{Introduction}

From its establishment, the United Nations (UN) with the institutional support of its sister organizations has been making efforts to protect and promote peace and security in the world. As an international inter-governmental organization, the UN serves as a framework for cooperative problem solving among the states including resolving inter-state conflicts and maintaining postconflict cum post-war peace and security. The belief in and value placed on preventive diplomacy by the former UN Secretary General Dag Hammarskjöld strongly influenced to vigorously pursue the peacekeeping operation as an approach to peace (Ariye, 2014). The principal organs responsible for the UN peacekeeping are the Security Council, the General Assembly, the Secretariat and the Department of Peacekeeping Operations which are involving in planning, 
mounting and supporting of UN-sponsored peacekeeping missions (Morrison et al., 1999). The core activities of UN peacekeeping are financed from the regular program budget and the individual operations are from a special account of the UN (Osmanczyk, 2003:1779). The UN has often taken measures to prevent disputes from escalating into war, to persuade opposing parties to use negotiation tables rather than force of arms, and to help restore peace when armed conflict does not break out. Peacekeeping is one of its major mechanisms to ensure peaceful resolution of conflicts in post-conflict situations (Agrawal, 2011).

The UN peacekeeping operations are varied in nature. Facilitating cease-fair agreements, mediating conflict situations to find solutions, monitoring emergency rule, and non-military aspects including provision of emergency relief and political reconstruction such as facilitating to restore representative democracy, protect and promote human rights and rule of law are some of the major activities associated with UN peacekeeping. In the post-world war world order, the UN peacekeeping operations have helped to restore peace and to avoid many conflicts transforming into civil war and war between states. However, with notable successes, it is also observed that throughout the history, particularly in the post-cold war context, the UN peacekeeping operations have faced serious challenges due to a number of issues pertaining to many aspects of peacekeeping operations. Although the UN and its influential members (or super powers) have been voicing and advocating for ensuring sustainable peace and security for the sake of future generations, their contributions to cope up with the issues challenging the successful implementation of UN peacekeeping missions are lacking or mostly negative. This puzzle warrant an academic investigation on 'why UN peacekeeping operations continue to face challenges while UN and member states are driving for peace?.' This article has attempted to outline the activities of UN peacekeeping operations, evaluate their achievements in fostering peace and security in conflict situations, and to examine the major issues challenging the activities and the final objectives of the UN peacekeeping operations.

\section{Methodology}

This is a qualitative study and descriptive and interpretive in nature. The study has incorporated only the secondary data which are available in different forms, such as journal articles, books, book chapters, reports of UN peacekeeping operation department, and other UN agencies. These sources have recorded the major activities of UN peacekeeping operations, their successful stories, and the issues associated with them. This study has specially examined the issues in terms of political, humanitarian and military aspects that are challenging the UN peacekeeping operations. The major finding of this study and the major arguments from the finding are presented in this paper as quotations, summaries, and authors' interpretive arguments.

\section{History of the UN Peacekeeping Operations: A Brief Introductory Note}

The primary reason for the establishment of the United Nations in 1945 was the maintenance of peace and security in the world. Peacekeeping is one of the major ways in which the UN helps to maintain international peace and security (Basu, 1993:261). Although, the word 'peacekeeping' was not anticipated in the UN charter, there are many provisions with regards to peaceful settlement of disputes, the use of force to end conflict, and how to maintain international peace and security. The basic UN peacekeeping principles were defined by the UN Secretary General Dag Hammarskjöld and the President of the UN General Assembly, Lester Pearson in response to the Suez Crisis in 1956 (Hatto, 2014). Accordingly, the UN defines peacekeeping as "an operation involving military personnel, but without enforcement powers, established by the United Nations to help maintain or restore international peace and security in areas of conflict" (United Nations, 1996:3). It is a technique designed to preserve peace, however fragile, where fighting has been halted, and to assist implementing agreements achieved by peacemakers (Castellan, 2010). The first UN peacekeeping operation was started in 1948 and 1949 in relation to the issues of Middle-East, and India-Pakistan border issues, respectively (Osmanczyk, 2003). Over the years, peacekeeping has evolved from a primarily military model of observing ceasefires and the separation of forces after 
inter-state wars to incorporate a complex model of many elements (such as military, police and civilian) working together to help lay the foundations for sustainable peace (Castellan, 2010). As to give more recognition and reputation, the UN has declared 29 May as international day for peacekeepers.

In the UN context, peacekeeping has been designed as the use of multinational forces under the UN command to help contain and resolve conflict between hostile states, and sometimes between antagonistic forces within a single state (Basu, 1993). The UN peacekeeping operations may be grouped into four categories of increasing complexity: (i) monitoring and observing missions, (ii) traditional peacekeeping, (iii) peacebuilding and (iv) peace enforcement (Sandler, 2017). It has political, military and humanitarian dimensions by way of intervention, mediation, supervision and observations, and assistance. The UN peacekeeping forces include troops and military observers, civilian police monitors and civilian support staff. Although UN is a legally authorized body to intervene in a conflict or war situation particularly through peacekeeping operations, it is necessary to affirm its three basic principles-consent, impartiality, and use of force only for self-defence.

The UN peacekeeping operations are varied in nature. Facilitating cease-fire agreements, mediating conflict situation to find lasting solution, monitoring elections and rule of emergency together with non-military aspects such as provisions for emergency relief, restoring representative democracy, promotion of human rights and rule of law as political reconstruction process are some of the different kinds of activities focusing in peacekeeping operations. The traditional model of UN peacekeeping evolved during the cold war era as a means of resolving conflicts between states. Peacekeeping at that time involved the deployment of unarmed or lightly armed military personnel between belligerent parties. The fall of Berlin wall induced the rising of intra-state conflicts which further resulted in a shift in the UN peacekeeping towards multi-dimensional operations. This has, in turn, led to an expansion of the non-military components of peacekeeping operations deploying civilian workers in key areas such as protecting and promoting rule of law, good governance, human rights including rights of women and children, together with relief and recovery of victims of conflicts and wars, and supporting to governance process in post-war or post-conflict transition process.

The UN peacekeeping operations include multi-dimensional activities connected with political, military, economic and humanitarian aspects. Political activities of peacekeeping are associated with restoring democracy, rule of law and good governance such as supporting to conduct free and fair elections including the monitoring, judicial reforms and empowerment of civil society. Supporting to disarmament, demobilization, reintegration, local security, and law and order are some of the major military activities of peacekeeping. Humanitarian activities of peacekeeping include relief distribution, providing shelter, sanitation facilities and supply of water and other basic amenities. The economic activities are associated with the presence of a peacekeeping mission in a certain location include first, services catering to foreigners, including those provided by hotels, restaurants, bars, and in the transportation and construction sectors; second, the high-and lowskilled jobs available to local staff associated with the mission; and finally, all the downstream economic impacts of these activities on other sectors (Jennings \& Boås, 2015). Although peace keeping has conflict reducing effect, all are not equally effective.

\section{Impact of the United Nations Peace Keeping Operations}

The United Nations is an authorized institution to respond to any kind of conflict situation though different means. Peacekeeping is one among them that have occupied a somewhat ambiguous place between diplomacy and democracy. Therefore, peacekeepers have become indispensable role in internal and international peace building. According to United Nations Department of Peace Keeping Operations (UNDPKO, 2019), since 1948, there were 71 peacekeeping operations initiated by the UN and 14 of them are under way at present. Over 124 countries contribute to the UN peacekeeping operations with nearly 100,000 troops, police and civilian personnel. Among them, more than 95 percent are missionaries with a mandate to protection of civilians. Over 600 human rights staff involving in supporting the promotion and protection of human rights. 
Most of the cold war peacekeeping operations were mainly confined to Middle East, part of Africa and other regional conflicts, those conflicts were mainly associated with de-colonization. These peacekeeping operations were largely military in composition and their tasks were to monitor cease-fire, control buffer zones, investigate alleged armed flows, prevent a resumption of hostilities and so on. They were to maintain calm on the front lines and give times for the peacemakers to negotiated settlement of disputes (Osmancavusoglu, 2000). During the second generation or phase, the UN peacekeeping operations wanted a great expansion among with new mandates. During this period, particularly during the early 1990s many of the operations lacked the explicit consent of classical operations and many operations had a new level of involvement. Many of the operations were deployed as part of negotiated political solutions. Electoral assistance, human rights monitoring, resettlement of refugees, police training, protection of humanitarian relief efforts, and disarmament and demobilization of armed forces were the major activities of peacekeeping operations during this period. It is worth noting that during this period, particularly in 1988, Noble Peace Prize was awarded to UN peacekeepers for their decisive contribution toward the initiation of actual peace negotiations in many conflict situations (Osmancavusoglu, 2000).

The failure learnt from the second generation of peacekeeping operations have resulted in UN taking up several new measures and strategies in order to improve the efficiency and effectiveness of UN peacekeeping operations. These measures and strategies were focused on '1992 Agenda for Peace' document that stressed the important of achieving sustainable peace (Nagar, 2016). As to ensure the measures and strategies to be effective, the Department of Peacekeeping Operation was established in the same year. From these initiatives, third generation of UN peacekeeping operations started. They were largely enforcement operations in nature and primarily involved in internal conflict mostly without the consent of conflicting parties as in Somalia and Bosnia (Osmancavusoglu, 2000). Since the start of 1998, there were 25 new UN peacekeeping missions, covering political, military and humanitarian activities.

Although the UN Peacekeeping operations or missions have shortcomings, in the last 2 decades, they worked effectively in establishing peace and resolving conflict in many parts of the world. Through these peacebuilding operations, the UN was able to transformed 4-5 major conflict into minor conflicts. The UN peace keeping operations have helped to serve thousands of human lost and displacement (See: Hegre et al., 2018). The UN peacekeeping operations have helped to prevent conflict from breaking out or recurring. Also, they have help to enable the cessation of fighting or reduce the intensity of violence in an ongoing conflict (Hultman et al., 2014; Beardsley \& Gleditsch, 2015). They were effective in fighting between the warring parties, reduce scope of violence by containing conflicts geographically, reduce duration of conflict locally, and were also effective in manging violence against civilians (Hegre et al., 2018). Peacekeeping operations have also helped to limit the spatial and temporal contagion of conflict, and were effective in reducing likelihood of conflict in neighbouring counties (Beardsley, 2011).

Similarly, the UN peacekeeping missions have also helped to increase the duration of postconflict peace. The impact of a peacekeeping operation is likely to last for a long time, reduce the lethality of ongoing conflict, increase the channels of conflict ending, and prevent contagion to neighbouring countries (Hegre, et al., 2018). Hegre at al. (2018:2) also found that the UN peacekeeping policies over the [15] years have been effective, however, UN could have done considerably better. They argue that the more UN is willing to spend on peacekeeping, and the more missions are provided with a strong mandate, the greater is the conflict reducing effect. By reducing conflict, peacekeeping can prevent displacement of civilians, thus further reducing the humanitarian suffering that extends beyond the countries (Hegre et al., 2018:2).

It is also argued that peacekeeping missions can also have positive economic effects in different ways. They help to increase agricultural product due to conflict reduction. They also help to increase labour productivity and taxation capacity. However, the effects of revenue windfalls diving from foreign aids, commodity price stocks, and oil and mineral discoveries are influential in the economic activities of peacekeeping. Peacekeeping missions directly boost demands for goods and services at development sites. Local economic recovery and institutional building can ensure a lasting peace with the afford of peacekeeping (See: Bove \& Elia, 2018; Hentges \& Coicaud, 2002).

The UN peacekeeping operations have also impact on human rights since human rights 
protection and promotion is often part of the UN peacekeeping mandates, and a core focus of UN peacekeeping operations. Most of the UN peacekeeping operations include human rights office and officers implementing specific human rights functions such as monitoring, reporting and mainstreaming (Castellan, 2010). Peacekeepers are expected to integrate human rights approach in their strategies. They commit to contribute to the protection and promotion of human rights, empower the population to assert and claim their human rights, and enable states and other national institutions to implement their human rights obligations and uphold rule of law. In this way, peacekeeping is identified as one of the most laudable conflict management mechanisms the UN has designed, originally for interstate conflict, to protect human rights during the cold war when the paralysis of the Security Council hindered its ability to respond to global security threats. The protection and advancement of human rights is a fundamental objective of the United Nations in its commitment to save future generation from the impact of wars. Therefore, the UN peacekeeping missions deployed in violent civil wars has increasingly expected to prevent and or halt human rights violation (Nsia-Pepra, 2014).

Albeit the positive and successful stories of UN peacekeeping, the peacekeeping operations have become more complex in nature because of the complex nature of inter-state and intra-state conflicts and the issues related to the many aspects of UN peacekeeping. The successes of the operations were always questioned and criticized because of challenges relating to the aspects of peacekeeping. The following section examines the major issues particularly in terms of political, humanitarian and military activities that impose challenges to the successful missioning of UN peacekeeping operations and implementation of programs.

\section{Issues that Challenge the Missioning of United Nations Peacekeeping}

Although, the UN has number of mechanisms, resolutions and resources that are aimed to enhance its peacekeeping operations successful, and the UN peacekeeping operations were successful to some extend to control violence and other casualties as well as to limit the extension of conflict, there are still setbacks and issues challenging the aiming of peacekeeping operations successfully. In the past, the UN peacekeepers were merely expected to separate hostile forces and observe cease-fire or truces. For this, offering collaboration and support by the conflicting parties were considered essential for the operation to be successful. However, in recent peacekeeping operations, due to the complexity of conflicts and involving actors, the UN has been acting without the clear consent to the parties in conflict which in turn imposes a number of issues and challenges. The new and complex environment, together with the ambitious objectives of the UN peacekeeping missions and ever-growing pressure on scarce resources, has made the UN more imperative than ever to think clearly about when and how the UN should become involved in peacekeeping operations.

There are different kinds of issues challenging the perfect functioning of UN peacekeeping operations. However, for this study, we consider the issues in terms of political, military and humanitarian categories are influential and seriously challenging the peacekeeping operations to a greater extent. The following sub-sections briefly examine the influential issues among them.

\subsection{Political Issues}

Political issues are influential in making the UN peacekeeping operations so difficult. Consent of host country, political stability of the post-conflict situation, political will of the host country and substantial financial and logistical support from the UN office are some of the important and influential issues among them which undermine the smooth functioning of peacekeeping.

Consent of host country: The UN has adopted fundamental principal that missions deploy only with the consent of host-state government and the other parties to a conflict. Obstructing the movements and activities of peacekeepers by the host-state government on number of ways, can prevent peacekeepers from implementing their mandate and also present serious risks to the peacekeepers' safety and security. As host country consent is a fundamental principle of UN peacekeeping, it means that the host country can also veto an UN peacekeeping operation. The 
UN Emergence Force-I was forced to withdraw once this consent had been removed by Egyptian government in 1967 and the efforts to persuade Israel to permit the stationing of United Nations Emergency Force (UNEF) troops on the Israeli side of the demarcation line were unsuccessful (Morrison et al., 1999:742). Such a situation, therefore, dictates that there is an inherent political difficulty in enabling or sustaining an UN peacekeeping operation due to the sovereignty of the state and the lack of political will in the UN or limited power of the UN to overcome the sovereign of the state on humanitarian grounds. As Sebastián and Gorur (2018) reveal, the absence of genuine host-state consent represents one of the greatest threats to the success of modern UN peacekeeping operations. They argue that without host-state governments' active support for peacekeeping missions to achieve their mandates, it is very difficult for the missions to develop clear and sustainable exit strategies, which necessarily involve handing over some tasks to government authorities (Sebastián \& Gorur, 2018:5).

Political stability of the post-conflict situation: Any UN peacekeeping operation depends on incountry political conditions combined with a limited mandate for UN peacekeeping operations that neither addresses the causes of tension or the effects of violence means, many UN peacekeeping operations are doomed to failure. The crisis in the UN peacekeeping in Somalia was a combination of political and social instability (Morrison et al., 1999:744). The collapse of state authority and control, and rebel insurgency has many consequences in peacekeeping such as breakdown of infrastructure, communications, transportation, and system for the distribution of goods and services, all of which lead to increasing tensions among the population. It was evident in the UN peacekeeping operations of the former Republic of Yugoslavia, Cambodia and Haiti too (Morrison et al., 1999: 747-750).

Substantial financial and logistical support from the UN office: Lack of international financial support to peacekeeping or less support or no support from all UN member countries is another major political issue which makes UN peacekeeping operations so difficult. It is observed that no government paid the agreed amount for the UN peacekeeping operations on time. The UN peacekeeping missions face cash-flow problems and financial strains due to the late payment and withholding of assessed contribution (International Peace Institute, 2019). Therefore, the financing of peacekeeping operations gave rise to considerable disagreement among member states (Osmanczyk, 2003). In the earlier years, the expenses of peacekeeping operations were assessed on member states at rate set in the regular budget scale. However, in December 2000, the General Assembly made a new scale, which was approved by consensus, the highest rate, that of the United States, was approximately 26.5 percent, but in 1996 the US Congress had unilaterally decided to cap the United States' rate at 25 percent (Osmanczyk, 2003:1779). Also, since 2016, the United States, started to withhold a portion of its contribution and build up arrears, which are placing a strain on UN peacekeeping. Therefore, the point is that UN peacekeeping missions are often 'on the ground' too late, and often under-funded which leads to immense difficulties in fulfilling their missions.

The political and financial supports of super powers and influence members in UN council is also another issue that really challenge the peacekeeping activities. Without the political support of the five permanent members of the security council and, in particular, the logistical, financial and political support of the United States, no operation has ever been completed successfully. At the same time, political commitment of the host country is also very much needed in a peacekeeping operation. However, UN peacekeeping operations were suffered by the limited political will or support of the host countries too, to enforce the mission mandate-the 'rules of engagement'-the extent to which an UN peacekeeping operation can 'enforce' its mission through defending itself and others. This was the reason for failure of the operations in Somalia and Haiti in relation to disarmament and demobilization after civil war (Berdal, 1996:30-32).

\subsection{Military Issues}

Like political issues, military issues also make UN peacekeeping operations difficult. Military personnel and their conduct in peacekeeping operations will influence the destiny of the operations. It is identified that the low-capacity of the peacekeeping forces is a major military issue in UN 
peacekeeping operations. Peacekeepers are not combat forces. They merely monitor previously agreed-upon cease-fires and truces. They have no authority for shooting whenever they need to fight with the rebel group to keep peace. They can't stop the genocides or human rights violations. But, they have to work among well-established rebel armed groups. It make challenge the UN peacekeeping forces. Somalia and Rwanda cases are clear evidences in this regard. In Rwanda, approximately 800,000 people were killed in one-month period by the armed groups (in-1994) during an UN peacekeeping forces were there (Miall et al., 2006:137). When Bosnian Muslim town of Srebrenica fell to a siege by Serb militias, during which 8,000 Muslims were killed under the eyes of the UN peacekeeping contingent deployed (Miall et al., 2006:137-138). This clearly indicates the limit of UN peacekeeping mandate to control violence or human rights violation during operations.

Commitment on rapid reaction of the member countries is one of the identified issues in UN peacekeeping operations. In the case of Rwanda, troop deployment took place months after they were committed; contingents were generally poorly equipped and ultimately only half of the required numbers were sent (Morrison et al., 1999:751). On the other hand, the most contributing countries have slow to accept and implement the practical measures required to match the political and rhetorical favour with which they endorse the development of a large number of civilian police to conflict area. In 1999, it became clear how serious staff shortages were when the UN almost simultaneously authorized for peacekeeping operations in Kosovo and East-Timor. According to the Brahimi Report, as of $1^{\text {st }}$ August 2000, 25 percent of the 8,641 Police positions authorized for UN peacekeeping operations remained vacant (Hansen, 2002:48).

It is also evident that internal coordination of multinational force leads to many problems in relation to communications and logistics. The lack of cultural understanding of local conditions combined with an ineffective mission undermines efforts of local police and other services to reestablish the 'rule of law.' Low standards of policing by the international contingent can have a devastating effect on peace operations. As Hansen argues, "perhaps the most severe consequence is a loss of credibility, respect and confidence among indigenous police force and population' (Hansen, 2002:50).

Misconduct, human rights violation and abuse of military forces are also issues which challenge the UN peacekeeping operations. There have been cases of misconduct among international peacekeeping forces in most operations, Cambodia being a case in point. Some contingents were guilty of gross misbehaviours, such as abusing the local population, blackmarketing and running prostitution business (See: Hatto, 2014:511-512; Hansen, 2002:50-51). There are many violation and abuse cases of peacekeepers in Iraq and Afghanistan peacekeeping operations too. Inefficiency and corruption also affect the credibility of UN peacekeeping operations. Sheri Prasso and Dzenita Mehic provides damning accounts of it in UN peacekeeping operations in Cambodia and Somalia (See: Woodhouse \& Ramsbotham, 1998:59). This raises questions about the commitment of UN peacekeeping troops to the missions and the lack of effective international policing of such interventions.

Absence of political trust and a basic willingness in demobilization is another major issue that challenge the operation of the UN peacekeeping mandate. The Khmer Rouge's refusal to adhere to the Paris agreement of October 1991 and the obstruction and intimidation of the state of Cambodia were the chief reasons for the failure of United Nations Transitional Authority in Cambodia (UNTAC) to demobilize the four factions in Cambodia (Berdal, 1996:21). Similarly, peacekeeping without ground peace is one of the biggest challenges in UN peacekeeping. For example, in Somalia, the UN peacekeeping troops were unable to disarm the combatants or impose peace due to the absence of ground peace (Osmanczyk, 2003:1778).

The UN structural weakness is another military issue in peacekeeping. The UN weakness of integrated planning mechanisms, antiquated procurement procedures, a semi-permanent funding crisis and a shortage of personnel and specialist units and technologies, logistic and transport deficiencies have all made critical situations in UN peacekeeping, especially in disarmament and demobilization operations. It was evident in the operations of Cambodia, Angola and Mozambique (Berdal, 1996). 


\subsection{Humanitarian Issues}

Providing humanitarian assistance in post-conflict situation is one of the functions of the third generation UN peacekeeping operations. Assisting to return the refugees and displaced people, distributing relief aids and providing essential amenities are some of the major duties of the UN peacekeeping humanitarian workers. They do it themselves and with the support of other International Non-Governmental Organizations (INGOs) and agencies. However, there are many issues which challenge the success of this part of operation. Political and social instability and natural disaster make considerable impacts in UN peacekeeping operations. To cite an example, a consequence of the breakdown of government, law and order and in combination with a period of serious drought during 1991 to 1992 was a time of considerable social distress in Somalia. By 1992, approximately 4.5 million Somalis (nearly half of the total population) were facing starvation and disease during the operation of peacekeeping mission (Morrison et al., 1999:744-746).

Relief distributions also become difficult because of lack of relief or coordination problems of the UN peacekeeping forces. Peacekeeping forces tended to assume a number of ancillary task at local or community level such as medical support, relief distribution, repairing basic infrastructure and initial assistance to small-scale integration activities. However, there are many problems, especially lack of co-ordination, commitment of civilians, political support in these activities.

Lack of cooperation within the peacekeeping mission is also one of the issues which make the UN peacekeeping operations difficult and challengeable. The capacity to fulfil the tasks of peacekeeping missions is greatly enhanced by the support of the military peacekeeping forces, Non-Governmental Organizations (NGOs) and other civilian staff. At the same time, civilian police are confronted with the needs and expectations of all their mission partners. For instance, the UN Refugee Agency, the United Nations High Commissioner for Refugees (UNHCR) in Kosovo was frustrated by the inability of the United Nations Mission in Kosovo (UNMIK) police to provide security for returning refugees (Hansen, 2002:63).

Military capture of humanitarian assistance is another major issue in relation to humanitarian operations of UN peacekeeping. In a protracted military civil war, it is very much difficult for the peacekeepers for humanitarian works. Capturing humanitarian and development aids, kidnapping, holding hostage and killing of humanitarian workers by the rebel or unidentified arms groups are some of the major issues that peacekeeping forces face. This was evident during the peacekeeping operations in many cases. Therefore, peacekeepers face challenges in distributing humanitarian assistance on times. Similarly, over amount of internal displacement and refugees in a post-conflict situation also make considerable challenges to the UN peacekeepers. All these issues, create number of humanitarian concerns and grievances that further increase complexities in conflict situations and peacekeeping operations.

It is worth noting that peacekeeping is a risky activity. Since 1948, up to 2017, more than 3,500 personnel have lost their lives in serving in the UN peacekeeping operations. Fatalities are high because the UN and the member states are failing to adopt and take necessary measures needed to operate securely in dangerous environment. As Santos Cruz et al., (2017:9) rightly pointed out, if the UN and troop or police of contributing countries do not immediately take responsibility for reversing this trend, they will be continuously placing personnel in harm way and compromising the mandate of UN peacekeeping operations.

\section{Concluding Remarks}

The UN peacekeeping remains one of the most effective tools to respond to the challenges of world peace and security. The UN peacekeeping continued to be a dynamic and demanding activity, responding to continuing turbulence in relations between states and to armed conflict within state borders (Boutros-Ghali, 1996). Every day, the UN peacekeepers protecting millions of civilians at conflict situations, supporting fragile political processes to find lasting solutions and building sustainable peace. However, as we argued earlier, the UN peacekeeping become so difficult because of many political, humanitarian and military issues. Therefore, the fact is the need for reforms in structures and processes of the UN peacekeeping operations to overcome the political, 
military and humanitarian issues and for the smooth functions of the operations. It is worth noting that the future of peacekeeping as a middle ground option between abstention and enforcement will depend on the capacity and willingness to reform and strengthen peacekeeping and to reconceptualize its role in conflict transformation (Woodhouse \& Ramsbotham, 1998).

Therefore, coordination of UN and other related organizations, more effectively linking of political, military and humanitarian components of UN peacekeeping operations and enthusiastic support and commitment of the global community, specially a friendly political and military support of super powers without using of 'decisive force' in future operations are very much needed in order to increase the efficiency and effectiveness of UN peacekeeping operations. Infect, there is a pervasive fear among the UN members that the organization has become a captive of its strongest member-at the moment, the United States of America.

Additionally, all components of the UN peacekeeping operations should respect International Law and customs of indigenous people of the country in implementing peacekeeping mandates. One of the major challenges in UN peacekeeping operations is the absence of permanent UN peacekeeping force. Therefore, a distinct, full-fledge UN peacekeeping force should be formed with adequate trained and specialized unit and personnel including other resources. The conceptual restructuring of the UN peacekeeping is also needed to be focus in advance in addition to the above focus. The mandate for peacekeeping missions or operations also must have clear and achievable mission that should integrate strategies to achieve sustainable peace. It is also necessary to find a comprehensive and integrated approach focusing on the importance of partnership and political cooperation with regional and sub-regional organizations in supporting the UN peacekeeping operations. This approach will strengthen coherence between political, military, humanitarian and development related activities of UN peacekeeping operations in future.

\section{References}

Agrawal, A. (2011). Role of UN in maintaining international peace and security. [Online] Available: https://papers.ssrn.com/sol3/papers.cfm?abstract_id=1948054 (21 May 2019).

Ariye, E.C. (2014). The United Nations and its peace purpose: an assessment. Journal of Conflictology, 5(1), 24-32.

Basu, R. (1993). The United Nations: structures and functions of an international organization. New Delhi: Sterling Publishers Pvt Ltd.

Beardsley, K \& Gleditsch, K.S. (2015). Peacekeeping as conflict containment. International Studies Review, $17(1), 67-89$.

Beardsley, K. (2011). Peacekeeping and the contagion of conflict. Journal of Politics, 73, 1051-1064.

Berdal, M.R. (1996). Disarmament and demobilization after civil wars: arms, soldiers and the termination of armed conflicts. Oxford: Oxford University Press.

Bouthros-Ghali, B. (1996). The $50^{\text {th }}$ anniversary annual report on the work of the organization. New York: United Nations.

Bove, V \& Elia, L. (2018). Economic development in peacekeeping host countries. CESifo Economic Studies, 64(4), 712-728.

Castellan, P.M. (2010). Human rights and peacekeeping. Suite: Peace Operation Training Institute.

Hansen, A.S. (2002). From Congo to Kosovo: civilian police in peace operations, New York : Oxford University Press.

Hatto, R. (2014). From peacekeeping to peacebuilding: the evolution of the role of the United Nations in peace operations. International Review of the Red Cross, 95(891/892), 495-515.

Hegre, H., Hultman, L \& Nygard, H.M. (2018). Evaluating the conflict-reducing effect of UN peacekeeping operations. [Online]: Available: https://www.pcr.uu.se/digitalAssets/653/c_653796-I_1k_pko_prediction_preprint_main.pdf (20 July 2019).

Hentges, $\mathrm{H}$ \& Coicaud, J. (2002). Dividends of peace: the economics of peacekeeping. Journal of International Affairs, 55(2), 351-367.

Hultman, L., Kathman, J \& Shannon, M. (2014). Beyond keeping peace: United Nations effectiveness in the midst of fighting. American Political Science Review, 108(4), 737-753.

International Peace Institute. (2019). Financing the UN peacekeeping: avoiding another crisis. New York: International Peace Institute.

Jennings, K.M \& Boås, M. (2015). Transactions and interactions: everyday life in the peacekeeping economy. Journal of Intervention and Statebuilding, 9(3), 281-295. 
Miall, H., Woodhouse, T \& Ramsotham, O. (2006). Contemporary conflict resolution. Cambridge: Polity Press.

Morrison, A., Cumner, S., Park, H \& Zoe, K.A. (1999). Peacekeeping. In L. Kurtz. (ed). (1999). Encyclopedia of violence, peace, and conflict (pp.735-753). London: Academic Press.

Nsia-Pepra, K. (2014). UN robust peacekeeping: civilian protection in violent civil war. New York: Palgrave Macmillan.

Osmancavusoglu, E. (2000). Challenged to United Nations peacekeeping operations in the post-cold war era. Journal International Affairs, 4(4), 3-6.

Osmanczyk, E.J. (2003). Encyclopedia of the United Nations and international agreements. London: Routledge Publications.

Sandler, T. (2017). International peacekeeping operations: burden sharing and effectiveness. Journal of Conflict Resolution, 61(9), 1875-1897.

Santos Cruz, C.A.D., Phillips, W.R. \& Cusimano, S. (2017). Improving security of United Nations' peacekeepers: we need to change the way we are doing business. [Online] Available: https://peacekeeping.un.org/sites/default/files/improving_security_of_united_nations_peacekeepers_repor t.pdf (20 May 2019).

Sebastián, S \& Gorur, A. (2018). U.N peacekeeping and host-state consent: how missions navigate relationship with governments. Washington D.C: Stimson Center.

Sigri, U \& Bas, U. (2014). An analysis of assessment of peacekeeping operations. The Korean Journal of Defense Analysis, 26(3), 389-406.

United Nations. (1996). The Blue Helmets: a review of United Nations peace-keeping. (3 $3^{\text {rd }}$ edi.). New York: United Nations.

Woodhouse, T \& Ramsotham, O. (1999). Encyclopedia of international peacekeeping operations. California: ABC-CLIO, Inc. 